\title{
The Adat Contributions for the Villages to Develop Independently: Cases from the Kei Islands, Southeast Maluku Regency
}

\author{
P.M. Laksono \\ Universitas Gadjah Mada \\ Email: pmlaksono@gmail.com
}

\begin{abstract}
Eventhough the district government has somehow acknowledged the failure of its own initiatives to empower its people, there must have been certain creativities or custom-related wisdom which seem to be able to independently respond to any development initiative. Precisely this article is trying to track creative moments when the customs and people writhing on the "bottom" of formal structures to contribute for a self modernization. Data from a short ethnographic study in the Kei Islands in mid 2016 shows the complicated moments of how indigenous communities survive while appropriating opportunities (friction) that is open due to failure of both the government and the market penetration to radically change the identity of indigenous local communities. Hence, modernization does not happen in a vacuum culture. Through their primordial taste, i.e. their identity, traditional leaders, businessmen and ordinary citizens creatively appropriating moments linkage to the world to declare local social differences.
\end{abstract}

Keywords: adat, bottom up iniatives, creative moments, custom, development iniatives, identity, Kei Islands, local community, local wisdom, modernization

\section{INTRODUCTION}

The gaps between the government's formal rhetoric for development or modernization and its actualization/realization in the society often become the reason to initiate observation and evaluation programs. Sometimes, with many certain arguments the development can be formally said (almost) done, though there has actually been no meaningful progress in the field. Based on this, an attempt would then be made to monitor or evaluate whether the programs would be ended or continued with certain conditions. Therefore, the result of the evaluation determines the continuity of the development program.

That is the usual cycle proposition of any development program that has been widely accepted in government bureaucracy, private businesses, and non-government organizations. If the rhetoric of its success is consistent with the fact in the field, the program is considered successful and it is very likely that it will continue. If the opposite occurs, the program will be assumed failed and, therefore, it should be terminates. Rhetorically, we have rarely noticed any development program initiated by the government that is declared failed by governement officials although what happens in the field is often different.

The study conducted by Center of Asia Pacific Studies Universitas Gadjah Mada (CAPS UGM) in collaboration with Bappeda (Regional Development Planning Agency) of South East Maluku Regency found that in the regency such a proposition is opposed. The government in South East Maluku Regency admitted that although 
many development (empowerment/modernization) programs initiated by various government agencies failed, the people continued to work hard until they could change and improve themselves (Laksono et al., 2015). I know many people in Evu, Debut and Revav who have independently appropriated new superior seaweed commodity for the regency that have been sold in international market since $2008 .{ }^{1}$

When the receivers of government's assistance (capital and tools e.g. boat, boat engine, ropes, life jackets, etc.) from the government failed and gave up, on the contrary other people who did not receive the assistance took over the tools, work hard, and succeeded. Seaweed farm needs continuous monitoring and maintanence to guarantee that the poles, the ris rope anhors, and the main ris rope are not damaged by big waves. Kei people who did not receive the assistance still cultivated seaweed in their own sea estate. These people are poor as they relay on rice at traditional markets and Raskin (rice for the poor from the government) for their daily need for food. Every day, they worked hard spending their time and energy on the sea taking care of their seaweed and abandon their embal (poisonous cassava) field. ${ }^{2}$ From the seaweed harvest they could send their children to universities in Yogyakarta, Malang, Surabaya and other cities in Java. Although they are the recipients of Raskin, they could afford to send their children to universities.

In such case, from inside the society itself, there must have been certain creativities or custom-related wisdom which seem to be able to independently respond to the changes, though it is still very much dependent on the government's initiative. Precisely the question would be at what conditions are the initiatives from the "bottom" (the local adat) able to contribute to the villages to develop independently?

\section{FINDINGS AND DISCUSSION}

\section{Local Identity (Custom) Movement}

Geographically (Bappeda 2014: 3-18), Kei Archipelago is situated at $131^{\circ}-113^{\circ} 5^{\prime}$ East Longitude and $5^{\circ} 32^{\prime}-8^{\circ} 00^{\prime}$ 'South Latitude, approximately across at the "bird's gizzard" of Papua Island in the North of Aru Archipelago. The size of Kei Archipelago is 4.212,54 $\mathrm{km}^{2}$, mostly consisting of sea and only one fourth of it $(1.031,81$ $\mathrm{km}^{2}$ ) is coral islands. As a whole Kei Archipelago consists of 70 islands, but only 12 islands are inhabited.

From the bird's eye it is clear that the settlement areas are mostly situated in the coastal area. Nevertheless, their life more dominantly depend on coconut plantation and recycled dry land cultivation. Not many of them depend on sea products although the coral islands have abundant and diverse sea biota. The meti areas (parts of the beach/coastal area that become dry at low tide) of almost all of the archipelago are rich in bia (a kind of sea shells), sea slugs, shells, and seaweed. The availability of water is relatively limited, so it is not enough to support rice field irrigation.

Since proliferated in 2003, Kei Archipelago is administratively divided into two autonomous areas: Tual City and South East Maluku Regency. In this article, both autonomous area, cosidering the social-cultural and ecological reason, are not separated exclusively although we tend to pay more attention on South East Maluku Regency. When proliferated in 2003, South East Maluku Regency initially consisted of six sub districts (Kei Kecil, Kei Barat, Kei Kecil Timur, Kei Besar, Kei Besar Utara Timur and Kei Besar Selatan). Then, in 2014 the six sub districts were proliferated further into eleven sub districts which consisted of 191 villages/ohoi (BPS 2015: 24).

The restructuration of the sub districts and villages in Kei Archipelago has a long and complicated history, full of conflict potential that has become latent in their regional administration management (governance) (Laksono 2002: 3240). During the colonial era until Negara Indonesia Timur (East Indonesian State) was formed, Kei Archipelago was one of the five onderafdeeling which were led by the controleurs under the power of a resident assistant from afdeeling Zuid Einlanden in Tual. Above him was a resident supervisor from Residentie Zuid Molukken and then above him was the Governor of Maluku. After Negara Indonesia Timur was dissolved, Governor Latuharhary decided to establish a regency for Aru, Kei, Tanimbar, Babar, and the islands in the Southwest on December 10, 1951. That the state was dissolved was the result of Abraham 
Koedoeboen and his friends' efforts to demand the autonomy for the Maluku Ter Selatan (The Southern Most of Maluku) since they became the parliamant members of Negara Indonesia Timur and the rejection of Kei people to join a sparatist movement, Republic of South Maluku. He announced this decision onboard Kasimbar (a ship) and in front of representatives of the people of Maluku Ter Selatan, who were invited to be present on the occasion. Subsquently, the regency is officially named Kabupaten Maluku Tenggara (South East Maluku Regency) with Tual as its capital. This was based upon the government regulation number 35, 12 August 1952. In this regency, Kei Archipelago is divided into two sub districts, Kei Kecil and Kei Besar (Laksono idem.: $35)$.

Since then, Tual has became a regency city and even Dullah Island where Tual is situated has been designated as a city. However, the administration of all villages in Kei Archipelago has not developed properly. When UndangUndang Desa 1979 (Village Legislation) was implemented and it required that a village must have its own territory, the crucial issue suddenly surfaced since then. Before the implementation of the legislation, the land in this archipelago was traditionally managed using personal network based on kinship and clan, but now the people had to live formally and spatially in different villages. This spatial system was not consistent with the existing social system. As an example, the Head of Kei Besar Sub district reported that only 44 out of 111 villages had exclusive territory (Berhitu, 1987: 26). This is reportedly because the head of the sub district poliferated the number of the villages in order to get more Bantuan Pembangunan Desa (Village Development Aid) from the central government. As a result, administration conflicts among the villages became latent issues.

Another important problem was the social structure of these villages. The administrations of the new villages were equal and positioned just below the head of the sub district and that was in conflict with the traditional hierarchy in these villages. Before the new system, based on traditional custom, Kei Archipelago was divided into three clusters or customary alliances: Lor Lim (Cluster Five), Ur Siu (Cluster Nine) and Lor
Lebai (Neutral Cluster). ${ }^{3}$ Every cluster assembled a ratschapen led by rat (kings). There were 10 ratschapen both in Lor Lim and Ur (lor) Siu. On the other hand, there were only two ratschapen in Lor Lebai (Rahail 1995: 9). J P Rahail (1992: 9) describes that lor was equal to a sub district, consisting of the several ohoi called utan. During the colonial period, the Dutch translated lor into rat-schaap. The distribution of the ratschap groups (Map 1) throughout the archipelago landscape is randomly scattered rather than forming a separate territorial blocks between one group and the others. This indicates that the division of the groups is more reserved through a mental map which is narrated orally and personally for generations (traditional) instead of being portrayed in black-and-white on a piece of paper. The map is more likely to portray the social relationship and kinship (marriage alliances between clans and descendants) between the rulers and amongst ratschap inhabitant.

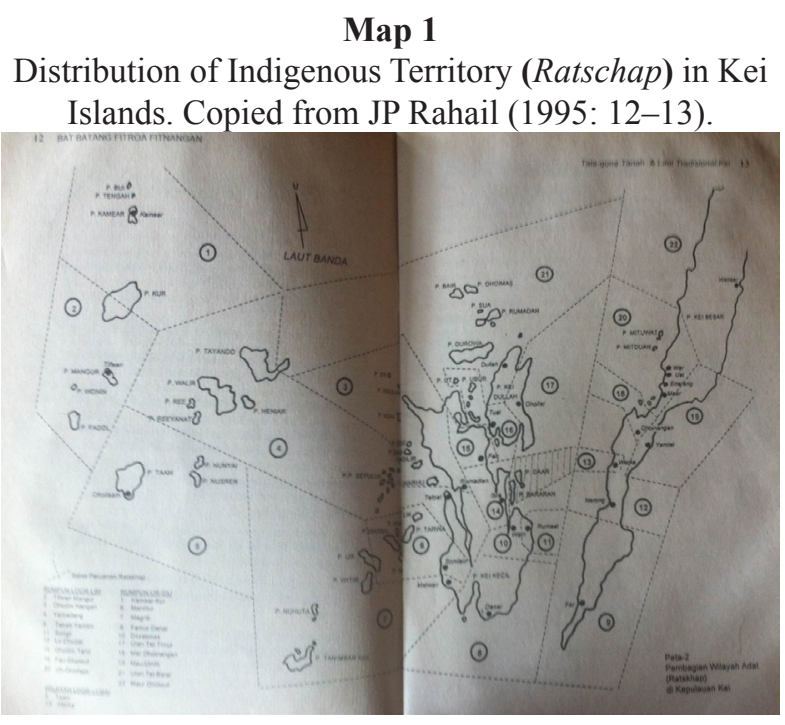

With one or two historical exceptions, there are usually orangkaya (lit. the rich or the big man) who rule the chiefs of the soa. These orangkaya were directly under the kings. In the new administration, the kings, orangkaya, or the chief of the soa has the same position as the sub district head or regents, as long as they lead a village. Ironicallya, nowadays, people still address the new villages as ohoi, which is a traditional term. Even though they are new, the villages seem just like the traditional ones, as if it had rooted 
far back in time. Therefore, it appears as though the sunken traditional hierarchy has been revived by the official hierarchy of modern "Indonesia" which is "dressed in" traditional ohoi $i^{4}$ instead. The difference is found in (see Map 2) the distribution pattern of the new sub district, which is illustrated in different colored blocks. It clearly indicates the area management that simplifies the personal and social relationships in the past and constantly turns it into a spatial object of Indonesia's rational/ modern (non-personal) administration.

The argument on who should sit on the new structure of the head of the village becomes intense. How they managed to get there; was it through the traditional and local personal relationships or through rational formal provisions based on the rules and regulations that apply nationally? In 1987, PM Laksono (2002:40) discovered that only two village heads owned the letter of appointment from the Regent, 47 village chiefs received the letter from the sub district chief, and 12 village chief did not possess one at all, out of a total of 61 villages in Kei Kecil. Meanwhile, it was reported that 109 villages received funds for rural development. Today, Southeast Maluku Regency is divided into 11 districts, consisting of 191 villages in the island of Kei Besar and Kei Kecil (Map 2). ${ }^{5}$

Map 2

Administrative Map of Southeast Maluku Regency (BPS 2015) ${ }^{6}$

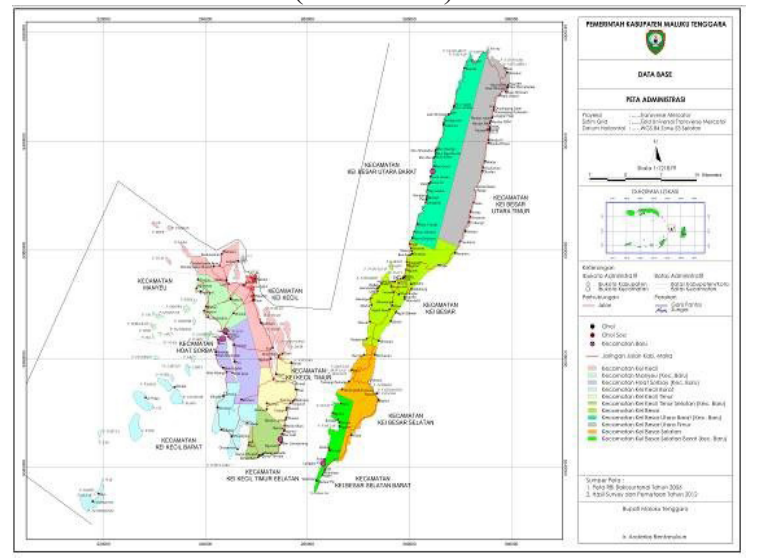

Out of the nearly two hundred villages, there are only 15 definitive villages (Laksono 2014: $29)$. Most of the others are only governed by interim (acting appointments). An interim or acting appointment is a public servant appointed directly by the regency. They have less authority compared to those of definitive village heads. Interim as a village chief indeed have the authority to take care of the village administration, but they do not have the authority to sign the village regulations. They also do not have the same influence as the head of ohoi back in the past. For this reason, the inhabitants have less respect for the interim as a role model in their daily life. People think of them as a representation of the state presence in the village that cannot be denied, and not as a leader that grow rooted in the local traditions. The legitimacy of interim as the village head is, of course, much less than the definitive village heads.

Institutional changes of the village administration, in addition to involving collisions between the spatial or social administration as mentioned above, has also become complicated by the fact that the collisions between the procedure for the appointment of the traditional officials through traditional personal kinship and the modern procedure through the merit system, equal rights, and direct election with one person one vote rule. In addition, there are conflicting problems in the relations between ohoi, due to the increasing village grants, the villages are continuously bloomed (there were 22 ratschapen, but now 191 villages). Back in the past, there were many chiefs of ohoi in Kei Islands who were yet to understand literacy and considered incapable of running the village administration in the context of the Republic of Indonesia. When the "Indonesianization" of the village structure occurred, they were replaced "temporarily" by the district government assigned officers until the day when they or their children or grandchildren could read and write. Therefore, the "temporal" structure switchover is only delay the radical restoration of the traditional hierarchy in the villages.

Although the children or grandchildren of the chiefs of ohoi are now well educated in reading and writing, even some of them already have a higher education, the position of the traditional village chiefs is not/yet restored. Rhetorically and formally (superficially) on paper, the government has reshaped the new villages in Kei Islands into ohoi. Hence, They look like the previous 
traditional villages though they are new. However, there are latent tensions hidden underneath the ohoi cover, the old structure that was once left manages to survive traditionally, and operationally in the everyday life there.

The old social structure exist doubtlessly and fought back publicly occasionally. Nick Sedubun (2014) in a discussion on "Biarlah Gereja Menjadi Gereja (Let the Church be the Church)" in December 2014, described in details how the old hierarchy, in the form of social stratification between mel-mel roa (newcomers) at the very top, ren-ren or mel-mel nangan (landlords) and iri-ri (captives/slaves) at the bottom of the hierarchy, remains the same. ${ }^{7}$ On the island of Kei Besar, in the everyday life to the worship spaces, the hierarchy is obviously still going strong in surviving although in Kei Kecil it has already weakened and only appears occasionally in traditional rituals, village meetings, and on the official inauguration of the village. Mel-mel dominance in the everyday life depicted by Sedubun (idem.), with various kinds of gradations, is still functioning on a reciprocal basis. Except in Ohoiwait village, Sedubun describes how the mel-mel praises themselves before the ren and iri-ri of Kei Besar. Upward social mobility of the iri-ri and ren-ren, with one or two exceptions, seems as if it was clogged by the domination of the mel-mel. They must migrate to the outside of Kei if they want to reach a higher social status. The supports from mel-mel that manage to achieve the highest formal positions in government agencies, both in Langgur and in Tual, may become a resource that reinforce the prestige and dominance of mel-mel over ren or iri-ri that otherwise have to depend merely on the agriculture and marine products in the villages. ${ }^{8}$

In an interview with Radio Idola Semarang and RRI Yogyakarta in 2016, I suggested that we consider such latency as a fact of acculturation crisis. There were a lot of experiences from the communities in other places who realized that its cultural disposition is not suitable enough to respond to both national and global structural pressure. As far as the discourse on the settlement patterns within the public administration system is concerned, the recognition of the kampung existence, which grows almost throughout the country, is absent. Meanwhile, our mind only tries to understand the fact that the settlement patterns in Indonesia is only in the mutually exclusive forms between villages (desa) and towns (kota). Kampung or areas in between a town or city and the desa administratively are considered almost nonexistent. According to Chris Baks (1988: 223) a kampung is representing a linkage between urban and rural which indicates a social transformation process. Though it is part of a town and its people tend to live away from agriculture, they have not been industrial either. However, their (rural) way of life is less consistent with their (urban) place of living. However, instead of recognizing its latent existent properly and in order to comply with the provisions of the law, we frequently find people desperately tend to turn the latency of the kampung explicitly into desa.

In the Kei Islands, the local governments have treated ohoi in the same way as the official villages even though ohoi has a complicated social history. Before the reform, the term ohoi was normally fused with the name of the villages as Ohoitel, Ohoitahit, Ohoijang, Ohoinol, Ohoilim, etc., but not used separately as a synonym of the word "village" as it is used nowadays. Therefore, the places that used to be called explicitly without the word ohoi like Debut, Evu, Danar, become Ohoi Debut, Ohoi Evu, and Ohoi Danar. The word ohoi is now explicitly become the synonym of the word "village" as stated on the village legislation in 2012 and plastered on nearly all the village gates.

Langgur, Rumaat, and Wain, e.g., in 1980s were managed as villages in Kei Kecil District. Today, Langgur has become the capital of Southeast Maluku Regency, Rumaat has become a district, and Wain has remained a village with a new name but it still feels like the original as Ohoi Wain. Nonetheless, as we shall see more clearly, the three locations have already started to leave the patterns of life of the village, where almost all of its citizens' lives depend on farming or fishing, equally and instinctively perform the rituals for generations, feel associated with and respect the common ancestor and comply the customary leadership. Even so, if we see it from their spatial and social density, lifestyle, and consumption cycle, these three villages have not fully changed into a town/city. The three villages' social and spatial densities are increasing, especially for 
Langgur and Rumaat, so it is more appropriate to say that they have changed into a town. I think it is true that the application of the word ohoi has brought back the identity of the old inclinations although it was originally used to embrace the new village governance according to their new law which changed its resource from the local goods (copra and embal) and sea products (lola, sea cucumbers, and fish) to APBN (State Budget).

Regarding the local identity movement to prepare for the modernization initiative, James T. Siegel (1997: 93) states that to be an Indonesian, one must feel the flows of world's communication. This can only possible with the existence of lingua franca, Bahasa Indonesia. At that time, because the local identity was mostly shown in the second language, Kei people, who lived and spoke their thought in their local language, felt that the connection between their own self and identity weakened when they were forced to participate in the topic of second language modernization. They have to translate things that they want to say into the second language (Bahasa Indonesia) in order to be connected with the new world. Things that were hard to translate were not only the richness of cultural knowledge, but also the identity, which could not be fully transmitted into the second language (see James T. Siegel, 1997). The leftover identity slowly dissipated in the middle of the past ohoi (village) life and the new yet-to-be-city life.

Occasionally, some of those pressured identities would pass into the (modern) topic because it will always seek the way out to get a full recognition in the communication. On May $5^{\text {th }}, 2016$, the Catholics in Langur celebrated the Ascension of the Lord in Langgur's church complex which had been renovated for years. They held the Mass in an emergency building, which had dents here and there; right next to it was the unfinished grand church. In the chapel which is in the emergency condition, we will immediately feel as if we were in the room (old and frail), which certainly will be abandoned and torn down so that a new church located next to it, soon be coming the real one to look toward the future.

In the middle of it, the dominance of Bahasa Indonesia in the Mass' liturgy slowly became apparent. Prayers, the Bible's reading, and the sermon were all in Bahasa Indonesia, continued

\section{Photo 1}

The old Langgur Catholic Church (left) is still functioning, meanwhile the new church (right) is under construction.

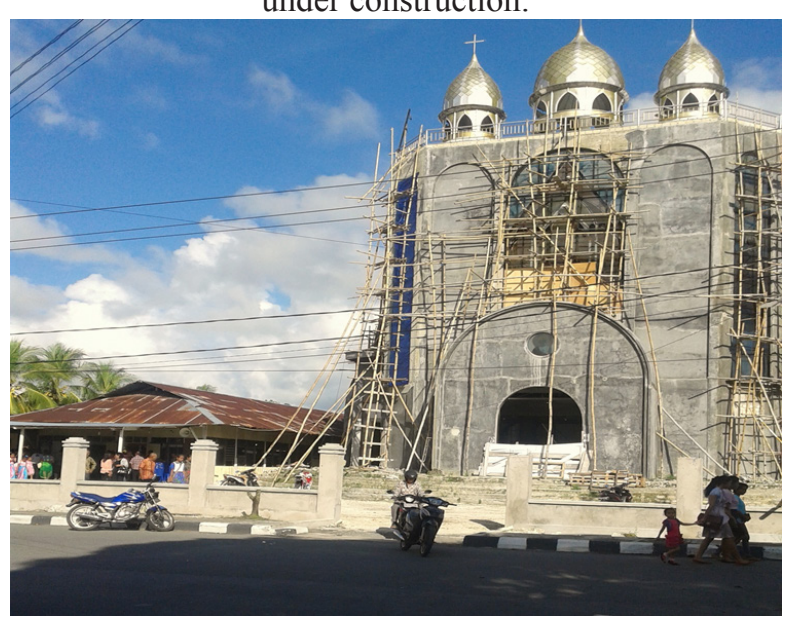

with a song sang by the choir in Javanese style, "Sorak Sorai". After the sermon, the priest sang Credo (Aku Percaya) and prayed The Lord's Prayer (Pater Noster) in Latin. However, after they reached the Agnus Dei prayer (Anak Domba Allah/Lamb of God), the choir and the people sang it in their local language, Kei. What happened after that was a room popped up for the Catholics of Kei to chant their identity to the maximum level, even more so when the song's lyrics were meant to ask for forgiveness and peacefulness to God. Those people were so excited that even when the conductor had stopped, they still sang the song until the end. This was the acculturation crisis when the original identity (primordial) was under pressure and seeking for its way out through the modernization's pressure of second/foreign language.

\section{Community Builds}

It is like building a new house above the pillars of the old house. For that, one could recklessly remove the old house with one hit using heavy equipment to flatten the land. In this case, he knew that the old house had to be destroyed. He did not want to learn about the minute details of the house and how it could be a slilit (a Javanese word means minor disturbance, but acute and hard to forget) for the peace of mind of the new house owner/occupant. That is why hysterical cries were always there whenever the eviction of the rumah 
liar (illegal houses) in Jakarta and any other big cities took place even though the government had provided apartments or flats as a substitute. If only the builders were not reckless, he would think about saving the walls here or there, this door or that door, the woods, and many other good things in the house. There are still many valuable things in the old house. It would be even more complicated if there were memories inside the rooms that could not just be abandoned along with the remaining pieces of the house, and forgotten when the people reside in their new house.

There are many details about the house stored inside one's heart that could at times spill out in the forms of words when someone talks about the history between him/her and the house. This is an event where the old house had carved a mark in his/her life, ${ }^{9}$ becoming an identity along with the signification of the new house forever. Like many others, the occupant, for example, would always recall, think about, and tell (the story) on how he acquired, built, and enjoyed that house; how much it cost, how much the other similar houses cost, and the current price of the old house. These talks had obviously inspired collectors and the dismantled (antique) house traders anywhere. The traders could creatively create some myths that change the old houses as a mark on their lives, for a livelihood.

Any livelihood, on which we depend our rights to eat, is closely related to the identity marking process, just like the creation of the house. Because of that reason, the Javanese, for example, likens the newlywed life with omah-omah (household), a moment when the couple has their own livelihood and no longer need financial support from their parents. The livelihood becomes significant, especially in its relation to the (history of) household. In the past, household is a part of daily social-cultural relation, temporary agreements between a husband and wife supporting each other in life. ${ }^{10}$ They live without differentiating their sexual roles to fulfill the daily necessity of a husband, wife, and their children (Illich 1982). This happens when the couple lives an entrepreneur life instead of being an employee.

The arrival of the funding source that followed the colonials in the Kei Island became the fundamental starting point. Adolf Langen, a German businessperson, was the first to launch logging and iron sawmill enterprise on the last decade of $19^{\text {th }}$ Century. At first, the Kei people refused to work in that business; they chose to live on their own with their palm plantation and sea products. These people did not have any desire to be a labor in Langen's company. Because of that, Langen imported migrant workers from China who were famous for their strength and diligence on logging and sawing woods. Unexpectedly, the migrant's cost became too much, so they took workers from Java, which ended up being too expensive too, aside from not strong enough for the work. Then, he gave a suggestion to the governor to send the missionaries so that the people of Kei are willing to change their mind and make it better for the government's development plan (Laksono, 2002).

Even though the unique historical event was not the sole reason, Catholicism bloomed in Kei and Maluku soon after that. Langgur grew into the central of Maluku and Southern Papua's diocese until the middle of 60's. Missionaries' works in the field of teaching, constructing, and medical services opened up various new job opportunities other than farming. Teachers and crafters who graduated from the Missionary school had contributed in the development of almost the entire Maluku and Papua. Kei's communities also started to spread itself away from their home island. The government's National Development Initiative in the era of Orde Baru (The New Orde) gave the workers from Kei a broader roaming destination range. In the villages, it was easy to meet a person, men or women, who had a working experience from Merauke, Sorong, Bintuni, Kaimana, Dobo, Benjina, Ambon, Surabaya, and many other places. Nowadays, more people get and finish their degree in Java's big cities, including Yogyakarta.

The experience of seeing the outside world had surely changed their lifestyle and mind. Right now, we will briefly see the cosmopolitan youngster's makeup and driving styles on the street. After walking out of the airport in Ohoi Ibra, we could immediately see the four-lane asphalt road. Taxi could go with the speed of $80 \mathrm{~km} / \mathrm{h}$ on it, and it only takes 10 minutes to reach Langgur. As we stepped into the people's houses, we would see that the electricity was turned on all the time; $\mathrm{TV}$ is everywhere, and snacks with various flavors 
(cheese, chocolate, and strawberry) are common. Do not ask about the politics. People everywhere keep talking about local and national politics. I have even heard that husband and wife nastily argued because of their preferences of regent candidate were different. Political discourse complicates the social differences among the Kei people. They are also affected by the conflict between religious congregations that afflicted Maluku during the last century's transition. Nevertheless, Kei people are able to be at ease quickly compared to the other Moluccan. They reconcile through a custom procedure ken sa faak (everyone admits their faults) to achieve unity ain ni ain (unity in diversity) (Laksono and Topatimasang, 2004).

In general, Mollucan people believe that Kei people still hold on to their customs. They have sacrificed a lot of energy as a charity so the oneness of the community and the facilities of life cycle were guaranteed. In daily terms of Kei women, the charity given in a form of goods or money, are called yelim, a contribution for custom activities. The amount varies, depending on the difference of necessities (euphoria or sorrow) and status/prestige discrepancy kinship/traditional relationship with the receiver. If it is in a form of labor/work helping one another especially for ohoi affair, such as mosque and church establishment, they will call it maren. Even though Kei wanderers have gone that far to Jakarta, many of them occasionally return home or transfer some money for maren. The grandmothers, widowers from Kei Besar and villages in Kei Kecil, who usually sell embal and vegetables day and night in Langgur market, admit that sometimes they run out of money if they come back home making yelim.

The determination to the custom is vividly flowing even closely related to economical practice flow in the market. In this case, Kei people admit that this custom movement depends on the authority and the exemplary of their board of custom leaders. Meanwhile, the leaders hardly have the formal authority in the village order administration. More than $90 \%$ of the village chiefs are temporary officials from civil servants chosen by the district authority (Laksono, 2014: ditto). They represent the country's interests more than they represent the custom's interests, so formal initiative for development tend to be impeded and turned over in this point. Under this formal structure the people with the guidelines of their custom community appear to organize themselves latently as alternative development initiator power.

When conducting research about Kei people's work ethic in 2014, a researcher (Aan Subhansyah) reported that in terms of daily economy/household, they tended to solve a problem individually. The community and local leaders did not interfere. Instead, people were still working and fulfilling their daily needs by gardening and catching fishes. Many of them said that the nature was relatively sufficient for eating and other necessities. The Poisonous Cassava (embal), the main source of carbohydrate for Kei people, can be planted and grow well in almost every places there. There are a lot of bananas and vegetables, too. Actually, all of the garden products could be turned into money. If only the people were willing to work hard, they would not run out of food stocks. A fisherman (40 years old) in Revav jokingly said that since he was a child, fish in the sea had never decreased in number, but now they have had earned their bachelor degrees. He meant that it was no longer easy to catch them - they were now smart to dodge from fishermen who wanted to catch them. Therefore, he said that people should be able to outsmart the fish.

In Revav village, we saw how people succeeded in turning the village that had been dirty into a clean and lively village. The houses that previously had had wooden thin wall and palm-leaf roof now it had cement wall and bluish tin roof and some of them had tiled floor. It happened because the people followed the example given by a pastor from Flores Island who worked relentlessly, "plunging" himself into the sea to show them how to cultivate seaweed their customary sea estate. We heard that one of the successful seaweed farmers, who bought equipment for seaweed cultivation from people of other villages who were some of the recipients of government's assistance. When we arrived in Revav, the pastor had been transferred to Tobelo, North Maluku. However, Revav people, both men and women, seemed to be working hard binding, planting, harvesting and drying their seaweed. They, as a church community that has embraced their custom, had succeeded in independently improving their own 
economy outside the formal structure of the village government. ${ }^{11}$

In any traditional community outside the formal structure, their economy is inseparable from the totality of the community's socio-cultural affair. Everyone with no specialization does the same work, in contrast with the industrial world where there are always specializations. They rely on exchanging goods with others (in Kei language it is called yelim) to fulfill their special necessities. In Kei mutual borrowing and exchanging embal, banana, tea leaves, cigarette, and salt, are daily exchange of each household. It even becomes the chain of communication that binds them in a community beyond the village territory and religion. Through yelim exchange and aid/help exchange (maren), Kei people have started to develop from the bottom.

From the top, development initiatives from the government tend to be treated as an individual (Laksono, 2014: idem) rather than a community business. They consider the government's empowerment programs aim to build village/ society merely an individual administration responsibility. This is in accordance with the tradition of national formal administration bureaucracy, whose responsibilities only include the completeness of formal administration elements, such as a complete financial report with the purchase receipts. Bureaucrats' responsibilities are considered completed when the report has been completed unlike any customary society that upholds their social morality when carrying out obligations or performing task for the people. Within the bureaucracy, responsibility seems to stop at the accountability and almost without moral responsibility. The bureaucrats individually detach themselves from the community. Moreover, their connection with the nation's interest is only formal administrative matter, a half-hearted commitment.

\section{CONCLUSION}

This article in particular has been trying to track creative moments when the customs and people writhing on the "bottom" formal structures to contribute for a self modernization. There we witnessed the complicated moments of how indigenous communities survive while doing appropriation opportunities (friction) that is open due to failure of both the government and the market penetration to radically change the identity of indigenous local communities. Finally, what happens is a lot of compromise. There are many deals on empowerment and social change on the part of government agencies that are sometimes overlooked even formally rejected, but silently while residents (others) to implement. From there we knew modernization does not happen in a vacuum culture. There is a primordial taste (such as mediated in their first language) they think as an identity. Traditional leaders, businessmen and ordinary citizens creatively appropriating moments linkage to the world to declare local social differences. They also latently maintain their customary sustainability.

When the Kei had to integrate themselves in the current national and global changes, they like to live immersed in two conditions. One their foot in the productivity of indigenous communities that require sacrifice/cooperation (ain ni ain). Their access to the setting and use of natural resources (land, forests, waters and coastal seas) still effectively determined, based on the exchange administration (yelim) follow the flow of the discourse (ritual) kin and social relations in the past. While it is practically the other foot simultaneously immersed in the vortex state and market power, which however had a very decisive change in taste and well-being. The only stratagem in order to survive in the maelstrom that is performed (alert) as individual opportunists, is waiting for a (sweet) opportunity to attract private gain.

\section{ACKNOWLEDGEMENT}

I would like to convey my gratitude to my coresearchers Christianto Wisma Nugraha, Suhatmini Hardiyastuti, Esti Anantasari, and Karina Ayu Rarasasri Gumilang at the Center of Asia Pacific Studies Gadjah Mada University, the Southeast Maluku Bappeda staffs, and many more people in the Kei islands. Thanks to their generous contribution that this article is available and accessible. This article is an additional product of our participatory action research funded by 2016 PUPT (Penelitian Unggulan Perguruan Tinggi) from the Ministery of Research, Technology, and Higher Education of the Republic of Indonesia. 


\section{REFERENCES}

Baks, Chris (1988). "Kampungisasi or Urbanization? Java's Saturation with Buildings, Houses, and dwellings," in David S. Moyer and Henri J.M. Claessen, Time Past, Time Present, Time Future: Essays in Honour of P.E. de Josselin de Jong. Dordrecht-Holland/ProvidenceU.S.A.: Foris Publications.

Barthes, Roland (1972). Mythologies. Translated by Annete Lovers. New York: Hill and Wang.

Berhitu, TH (1987). Laporan Perkekmbangan Pelaksanaan U.U. No.5 Tahun 1979 tentang Pemerintahan Desa. Unpublished report to the Bupati of Maluku Tenggara Regency forwarded to the Governor of the Province of Maluku.

BPS (2015). Maluku Tenggara Dalam Angka. Langgur: Badan Pusat Statistik Kabupaten Maluku Tenggara (Central Board of Statistics, Regency of Maluku Tenggara).

Illich, Ivan (1982). Gender. New York: Pantheon Books.

Laksono, P.M. (2002). The Common Ground in the Kei Islands: Eggs from One Fish and One Bird). Yogyakarta: Galang Press.

Laksono, P.M., Topatimasang, Roem (ed.) (2004). Ken Sa Faak: Benih-benih Perdamaian dari Kepulauan Kei. Tual-Yogyakarta: Nen Mas Il-Insist Press.

Laksono, P.M, et.al. (2014). Kajian Etos Kerja Masyarakat. Laporan Akhir Kerjasama Pemerintah Kabupaten Maluku Tenggara dan Universitas Gadjah Mada Yogyakarta. Langgur: Badan Perencanaan Pembangunan Daerah Kabupaten Maluku Tenggara.

Rahail, J.P. (1994) Larvul Ngabal. Seri Pustaka Khasanah Budaya Lokal \#1. Jakarta: Yayasan Sejati.

(1995). Bat Batang Fitroa Fitnangan: Tata Guna Tanah dan Laut Tradisional Kei. Seri Pustaka Khasanah Budaya Lokal \#4. Jakarta: Yayasan Sejati.

Sedubun, Nick (2014). Opini Teologi: Strata Sosial. Senin, 14 April 2014. ohoi-ra.blogspot. com/2014/12/biarlah-gereja-menjadi-gerejal. html.

Topatimasang, Roem (ed.) (2004). Orang-orang Kalah: Kisah Penyingkiran Masyarakat Adat Kepulauan Maluku. Yogyakarta: Insist Press dan Perkauman Pendidik untuk Keadilan Sosial (PERDIKAN).
Siegel, James T. (1997) Fetish, Recognition, Revolution. Printon, New Jersey: Princeton University Press.

\section{(Endnotes)}

1 Empirical evaluation on the cultivation of seaweed in South East Maluku Regency, see for example Wellem Anselmus Teniwut and Jamaludin Kabalmay (2014) found that factors of pests and diseases, low quality seeds, low selling prices, and misuse of government' financial assistance had become the common causes for the decrease of seaweed cultivation in South East Maluku http://www.academia.edu/18180906. This was ironic considering the fact that since 2008 the government had given the assistance to 374 (village/ ohio) seaweed farmer groups that spread in eleven sub districts (ditto).

2 The story of the abandonment of embal fields due to the people's busy work in taking care of seaweed farms seemed to have widely spread (Sedubun 2014).

3 Such cluster divisions (branching) are common throughout Maluku and they are called Patalima, Patasiwa, and Patasela (Rahail 1995:8).

4 Ohoi is the smallest residential unit similar to a kampong (Rahail 1994:9).

5 Based on Legislation No. 31 Year 2007, 10 July 2007 regarding the proliferation of Tual City, Southeast Maluku Regency was also proliferated with Langgur as its capital. Government Regulation No. 35 Year 2011, 20 July 2011 moved the regency capital from Tual City to Langgur City in Kei Kecil District. Langgur City comprises eight ohoi (village/ kampong) and one kelurahan (urban village): Ohoingur - Ohoi Wearlilir - Ohoi Faan - Ohoi Ohoiluk - Ohoi Ngayub - Ohoi Loon - Ohoi Gelanit - Ohoi Kolser and Kelurahan of Ohoijang Watdek. Because the Government Regulation No 35 of 2011 concerning the capital movement of Southeast Maluku Regency was handed on 8 October 2011, the DPRD (parliament) session set this date as the anniversary of Langgur.

6 This map is copied in 2014 from the data base of the district government of Maluku Tenggara with the courtesy from the Bappeda Kabupaten Maluku Tenggara.

7 The hierarchy from the pre colonial period when the entire Nation was involved in slave trade survived even though the Dutch East Indies colonial had officially abolished it in 1869 .

8 ohoi-ra.blogspot.com/2014/12/biarlah-gerejamenjadi-gereja1.html. 
9 In this case, signification has occurred in that house. As on what signification is, see Roland Barthes, Mythology.

10 "Under the reign of gender, men and women collectively depend on each other; their mutual dependence sets limits to struggle, exploitation, defeat. Vernacular culture is a truce between genders, and sometimes a cruel one.... While under the reign of gender women might be subordinate, under any economic regime they are only the second sex. They are forever handicapped in games where you play for genderless stakes and either win or lose." (Illich 1982: 178).

11 At the time the village was still governed by a female teacher civil servant who had been appointed temporary village chief. Only a handful of (one or two) women became a village chief. Considering that their custom treasured women, so it should be understood that because their undefined position status, the people followed model leader outside the structure of the village government. 